\title{
Physical Therapy Reviews \\ Can physical activity be used to maintain cognitive function in nursing home residents with Dementia? A literature review. \\ --Manuscript Draft--
}

\begin{tabular}{|c|c|}
\hline Manuscript Number: & PTR-007-552R2 \\
\hline Full Title: & $\begin{array}{l}\text { Can physical activity be used to maintain cognitive function in nursing home residents } \\
\text { with Dementia? A literature review. }\end{array}$ \\
\hline Article Type: & Systematic Review \\
\hline Keywords: & Dementia; nursing home residents; cognitive function; physical activity, review \\
\hline Corresponding Author: & $\begin{array}{l}\text { Jonathan Mark Williams, PhD } \\
\text { Bournemouth University } \\
\text { Bournemouth, Dorset UNITED KINGDOM }\end{array}$ \\
\hline \multicolumn{2}{|l|}{$\begin{array}{l}\text { Corresponding Author Secondary } \\
\text { Information: }\end{array}$} \\
\hline Corresponding Author's Institution: & Bournemouth University \\
\hline \multicolumn{2}{|l|}{$\begin{array}{l}\text { Corresponding Author's Secondary } \\
\text { Institution: }\end{array}$} \\
\hline First Author: & Nicole Learner \\
\hline \multicolumn{2}{|l|}{ First Author Secondary Information: } \\
\hline \multirow[t]{2}{*}{ Order of Authors: } & Nicole Learner \\
\hline & Jonathan Mark Williams, PhD \\
\hline \multicolumn{2}{|c|}{ Order of Authors Secondary Information: } \\
\hline Abstract: & $\begin{array}{l}\text { Background: Dementia is a noncommunicable disease with no effective prevention, } \\
\text { treatment or cure. Evidence is emerging for the use of exercise to decelerate cognitive } \\
\text { decline; however, few studies exist among nursing home residents and an optimum } \\
\text { exercise protocol has yet to be determined. } \\
\text { Objectives: To determine the effectiveness of physical activity in maintaining cognitive } \\
\text { function in nursing home residents with Dementia. } \\
\text { Methods: Databases searched included CINAHL, MEDLINE complete, SPORTDiscus } \\
\text { and ScienceDirect. Six relevant studies were identified and critically appraised using } \\
\text { the Effective Public Health Practice Project Quality Assessment Tool. } \\
\text { Results: All trials included different exercise programmes with various activity types } \\
\text { and duration; all control interventions were social activities. Three studies } \\
\text { demonstrated improved cognition in the intervention group, whilst one study observed } \\
\text { a slower decline. Four studies found statistically significant cognitive decline in the } \\
\text { control groups. Two studies observed no significant changes in either the intervention } \\
\text { or control groups. Overall, there is moderate-to-strong evidence that physical activity } \\
\text { can effectively maintain cognitive function in nursing home residents with Dementia. } \\
\text { Conclusions: All interventions had a favourable effect on cognition. Results suggest } \\
\text { that aerobic exercise of longer duration may be most effective for those with mild-to- } \\
\text { moderate cognitive impairment; whilst multimodal programmes may be most effective } \\
\text { for moderate-to-severe Dementia. Combining an exercise programme with standard } \\
\text { daily activities appears no more effective than exercise alone. Future research should } \\
\text { aim to determine an optimum exercise protocol and whether the positive effects on } \\
\text { cognition can be maintained long-term with continued exercise. }\end{array}$ \\
\hline Funding Information: & \\
\hline
\end{tabular}


Title

Can physical activity be used to maintain cognitive function in nursing home residents with Dementia? A literature review.

\section{Authors}

Nicole Learner ${ }^{\phi}$,

Jonathan M. Williams ${ }^{\phi *}$.

${ }^{\phi}$ Faculty of Health and Social Sciences, Bournemouth University, Royal London House, Christchurch Road, Bournemouth, Dorset, BH1 3LT, UK.

${ }^{*}$ Corresponding author

Tel: +44 (0)1202 962478

e-mail: jwilliams@bournemouth.ac.uk 
I enjoyed reading this literature review on the use of physical activity to maintain cognitive function in residential care. Overall, this was a very well written article. I note that the authors have addressed the first reviewers comments, however reading the revised manuscript, there is still potential to improve the balance between the Results and Discussion (see first reviewer comments 4 and 5).

I would suggest including more narrative detail on the participants and interventions in the Results section. Participant age, sex, baseline cognitive score and activity/frailty level, and specifics on the nature of the interventions (what was in a multi-modal programme?) - the 'ins and outs of type and duration' of the interventions should all be in the Results. It will then be easier to synthesise this information in the Discussion section to give a more concise, cohesive message. There are some important points made in the Discussion, such as the need to consider frailty when prescribing physical activity, so reducing the length of the Discussion section will allow these key messages to stand out.

Many thanks for these comments.

The results sections has been modified to include the details suggested.

The discussion has been edited to reduce its length whilst maintaining the key messages. 
1 Can physical activity be used to maintain cognitive function in nursing home 2 residents with Dementia? A literature review.

Background

Dementia is a noncommunicable disease with no effective prevention, treatment or cure. ${ }^{1}$ Alzheimer's disease (AD) is the most common type of dementia with twenty-six million people affected worldwide; consequently, this is described as a global epidemic which is projected to increase as a result of aging populations. ${ }^{2}$ Many animal studies have demonstrated that physical activity can attenuate neuropathology associated with $A D,{ }^{2}$ whilst emerging evidence has shown improvements in cognitive and motor function and performance of activities of daily living by increasing the amount of exercise in community-dwelling older adults with AD. . $^{3,4}$ However, few studies exist among nursing home residents and an optimum exercise protocol has yet to be determined. Subsequently, current UK guidelines provide limited recommendations on exercise or long-term management of dementia, with physiotherapy assessment and advice not considered routine care. ${ }^{5}$ Therefore, there is a need for a systematic review of the literature synthesising contemporary knowledge. The aim of this systematic review was to determine the effectiveness of physical activity in maintaining cognitive function in nursing home residents with dementia and explore the literature for recommendations on exercise protocol development.

\section{Methods}

\section{Search Strategy}

22 This review systematically searched the databases Science Citation Index, Social Sciences

23 Citation Index, PsycINFO, CINAHL, MEDLINE complete, PsycARTICLES, SocINDEX, SPORTDiscus,

24 ScienceDirect and Education Source in November 2015. Search terms included Dementia,

25 "physical activity", "cognitive function" and "nursing home". All search terms incorporated

26 Boolean logic (Table 1). The search generated 149 potential articles published between 2000

27 and 2016 which was subsequently limited to the English language and peer reviewed journals. 
Following removal of duplicates, studies were screened by titles and abstracts against inclusion and exclusion criteria. The same process was then adopted to review full texts of remaining studies. No reference lists from selected articles were screened for additional references. The search strategy is presented via the flow chart in figure 1.

[Figure 1 near here].

$34 \quad$ [Table 1 near here].

\section{Inclusion and Exclusion Criteria}

37 Only Randomised Controlled Trials (RCTs) or Controlled Clinical Trials (CCTs) were included in this review as the aim was to explore the efficacy of an intervention. Participants in both intervention and control groups needed to have a formal diagnosis of dementia and be residing in a nursing home from the start of the trial. Therefore, studies were excluded if participants were community-dwelling older adults with mild cognitive impairment or no clinical diagnosis of dementia. Studies were considered for inclusion if they investigated the effectiveness of any physical activity on cognitive function. Although the type of exercise was not specified, the intervention had to be a structured programme incorporating gross motor activity that was results relating to cognition were presented separately from the other measures.

\section{Quality Index}

51 The Quality Assessment Tool for Quantitative Studies was used to assess the methodological quality of the selected studies. ${ }^{6}$ Previous studies have demonstrated the effectiveness of this tool with excellent inter-rater reliability. ${ }^{7}$ All studies were reviewed by the lead investigator with uncertainty resolved by consensus.

\section{Results}


The search provided five RCTs and one CCT which matched the inclusion criteria. Data extracted

57 from these studies are presented in Table 3.

Four RCTs scored strong and one RCT scored moderate on the EPHPP Quality Assessment Tool. ${ }^{6}$ However, the CCT was rated weak which subsequently reflects the hierarchy of evidence scale (Table 2). ${ }^{8}$

The studies included in this review had small sample sizes and the three trials with the least participants did not conduct a power analysis, ${ }^{9,11,12}$ whereas those with larger samples did. ${ }^{10,13,14}$ Although, it should be mentioned that Stevens and Killeen ${ }^{10}$ did not achieve the numbers calculated from the power analysis; perhaps reflecting the fact this was the only RCT to be rated moderate by the quality assessment tool. ${ }^{6}$ Additionally, participants were not randomly selected to enter the trials from their respective nursing homes and thus could only be scored as 'somewhat likely' to be representative of the target population. ${ }^{6}$ Therefore, it is possible that both selection bias and small sample sizes reduce the generalisability of findings. Nevertheless, the included participants do represent widely accepted statistics on the prevalence of $A D$, namely relating to age and gender. $81 \%$ of people with $A D$ are aged over seventy-five, whilst $A D$ and other dementias are more prevalent in women. ${ }^{16}$ This is echoed in all studies which included more females and had average ages of participants above eighty. Additionally, there were consistent results across the six studies which were all conducted in different countries. Still, two studies only had $60-79 \%$ of participants completing the study and neither used intention-to-treat analyses. ${ }^{10,11}$ Whilst this may increase the risk of attrition bias, these two studies were rated weakest by the quality assessment tool and thus the results may be more questionable. Out of the remaining four studies, only Telenius et al. ${ }^{14}$ state whether there were significant differences in characteristics between those who completed the study and those who dropped out. This decreases the generalisability of findings as attrition may preferentially select for those responding to the intervention. ${ }^{9,12,13}$ Finally, no study reported that participants were blinded to the research question or group allocation. The importance of this methodological flaw could be questioned as this method reflects patients in practice whom are aware of the treatment they receive and the intended outcomes. 
[Table 2 near here].

85 All studies used the Mini Mental State Examination (MMSE) to screen participants' stage of

108

109

110 dementia for inclusion. Venturelli et al. ${ }^{12}$ included five male and thirty female participants with moderate-to-severe cognitive impairment, an average age of eighty-four \pm five and no mobility limitations. The $\mathrm{CCT}^{11}$ entered four male and eleven female participants with mild-to-severe cognitive impairment, ages ranging from seventy-four and ninety-two. These participants were very frail, relying partly or constantly on walking aids. Kemoun et al. ${ }^{9}$ included eight males and twenty-three females with moderate-to-severe cognitive impairment, an average age of $81.8 \pm$ 5.3 and the ability to mobilise ten meters without assistance. Another $\mathrm{RCT}^{14}$ entered forty-three male and one hundred and twenty female participants with moderate cognitive impairment, an average age of $86.7 \pm 7.4$ and walking six meters with or without a walking aid. Stevens and Killeen ${ }^{10}$ included nineteen males and fifty-six females with mild-to-moderate cognitive impairment, an average age of 80.5 and were physically capable of undertaking gentle exercise (this included frail persons and wheelchair users). Finally, another $\mathrm{RCT}^{13}$ entered eighteen male and seventy-nine female participants with mild-to-moderate cognitive impairment, an average age of 85.4 and walking short distances with or without a walking aid.

All trials included different exercise programmes with various activity types and duration; however, all control interventions were social visits or activities. Venturelli et al. ${ }^{12}$ conducted a twenty-four week walking programme for thirty minutes, four times per week; whilst another study followed the same intervention with thirty minute sessions, five times per week, for six weeks $^{13}$. Steven and Killeen ${ }^{10}$ included a twelve-week programme consisting of thirty-minute aerobic exercise sessions, three times per week; the participants in the study by Telenius et al. ${ }^{14}$ undertook a twelve week strength and balance programme for fifty-to-sixty minutes, twice per week. Kemoun et al. ${ }^{9}$ combined walking, equilibrium and stamina exercises for one hour, three times per week, for fifteen weeks; whilst Thurm et al. ${ }^{11}$ also conducted a multimodal programme including strength, co-ordination, balance, flexibility and stamina exercises; however these were chair-based with forty-five minute sessions, twice per week, for ten weeks. 
111 Only Kemoun et al. ${ }^{9}$ demonstrated a statistically significant improvement in cognition following

112 the exercise intervention, whilst two studies found improvements but which did not reach

113 statistical significance. ${ }^{10,11}$ Venturelli et al. ${ }^{12}$ demonstrated a slower decline in cognition for the

114 intervention group but these changes were not statistically significant, although they do

115 suggest a stabilization of cognitive decline. However, four studies showed significant cognitive

116 decline in the control groups following the trials. ${ }^{9-12}$ Two studies observed no significant

117 changes in either the intervention or control groups. ${ }^{13,14}$

118 Overall, there is moderate evidence that physical activity can effectively maintain cognitive

119 function in nursing home residents with dementia. ${ }^{15}$

120 [Table 3 near here].

121 Discussion

122 Exercise Interventions (Type, Frequency, Intensity, Duration)

123 The results suggest that certain exercise types may be more beneficial at different stages of

124 dementia. [Two studies investigated the effects of aerobic exercise in those with mild-to-

125 moderate cognitive impairment. ${ }^{10,13}$ Since similar frequency and duration of sessions were also

126 used, it appears that Stevens and Killeen ${ }^{10}$ achieved better outcomes with a longer programme

127 (twelve weeks). This same programme duration, also for those with moderate dementia, was

128 used by Telenius et al. ${ }^{14}$ but incorporating a strength and balance programme. However,

129 Stevens and Killeen ${ }^{10}$ again demonstrated greater improvement. Therefore,] it appears that

130 aerobic exercise of a longer duration may be more effective than a strength and balance

131 programme in maintaining cognitive levels in those with mild-to-moderate dementia. In

132 contrast, although not significantly, those with moderate-to-severe dementia demonstrated

133 cognitive decline with aerobic exercise alone, ${ }^{12}$ but significant improvement via a multimodal

134 programme of a shorter duration. ${ }^{9}$ This suggests that multimodal exercise could have more

135 beneficial effects on cognition than single exercise interventions for those with moderate-to-

136 severe cognitive impairment. Overall these results provide evidence of a varied effect based on 
137 baseline cognition and exercise type, suggesting a stratified approach may be necessary to optimise the effect.

Observations of health status may provide explanations for the response to certain exercise types in accordance with the severity of cognitive decline. Interestingly, participants with mildto-moderate cognitive impairment were physically frailer with greater co-morbidities, including cardiovascular disease (Table 3). Therefore, improvements from gentle aerobic exercise alone support the widely accepted notion that the greatest gains are achieved when sedentary people become more active, including better cognitive function. ${ }^{17}$ Additionally, the need for a longer aerobic programme perhaps reflects the time required to achieve beneficial effects on the cardiovascular system, ${ }^{13}$ with increased cerebral perfusion arguably able to reduce neuronal cell death associated with Alzheimer's disease, as well as promote neuroplasticity. ${ }^{3}$ In contrast, studies investigating moderate-to-severe dementia included less co-morbidity or those which could be considered as less life-threatening, ${ }^{11,12,14}$ whilst co-morbidities in one study were unknown. ${ }^{9}$ Participants were also more physically capable with one study only including those with absence of mobility limitations. ${ }^{12}$ Perhaps then, a multimodal programme was most effective for these participants as it provided higher intensity exercise targeting multiple body systems over and above their previous activity levels. Overall, the stage of Alzheimer's disease and other dementias should be taken into account when selecting the most appropriate exercise type, whilst also considering the pathology's links to other co-morbidities, notably, cardiovascular disease. ${ }^{16}$

Comparing all six studies, a fifteen-week multimodal programme proved to be the most effective exercise intervention as this was the only study to achieve statistically significant improvements in cognitive function. ${ }^{9}$ Since the frequency, intensity and duration of this programme were all greater than the other studies, and due to the heterogeneity of the interventions, it is difficult to determine whether one, some, or all of these factors are responsible for the enhanced effects. Equally, as previously discussed, the participants' cognitive levels and physical capabilities in relation to the intervention may have also had an effect. Nevertheless, the result that a multimodal programme demonstrated the most 
beneficial effects on cognition reflects the American College of Sports Medicine guidelines for older adults, ${ }^{18}$ which recommend the inclusion of aerobic, strength and flexibility training within an exercise programme for this age group. The same recommendations are also made by the World Health Organisation and the Department of Health. ${ }^{17,19}$ Whilst each of these guidelines discuss the importance of tailoring the recommended dosages to individual need and capabilities, including for those with physical and mental disability; the emphasis on retaining cognitive function is placed mainly upon the population at risk of developing dementia, rather than individuals already living with the condition. This arguably limits the appropriateness of these guidelines to the target population of this review.

Similarities do exist between some of these recommendations and the findings from this review, specifically relating to exercise intensity. The guidelines indicate that moderate-tovigorous intensity activity provides greater health benefits, and this also could be suggested from this review, in relation to improving cognitive function in residents with dementia. Although no standardised measure of intensity was used across all six studies it can be assumed that some interventions were more intense than others. Two studies investigated the effects of a walking programme, however, one instructed participants to walk at a self-selected speed with the inclusion of short rest periods, ${ }^{13}$ the other to walk at the fastest pace possible without stopping. ${ }^{12}$ Whilst both studies maintained cognition levels, the latter of the two (higher intensity programme) maintained cognitive function over a six month period, suggesting this intensity can maintain cognitive function in the long term. Similarly, whilst the chair-based multimodal programme demonstrated improvements in cognition, these results were not significant; ${ }^{11}$ yet, other multimodal programmes which included walking and the use of an ergocycle achieved significant improvements in cognitive function. ${ }^{9}$ Additionally, both interventions which could be considered higher intensity demonstrated improvements in both cognitive and motor function, ${ }^{9,12}$ including specific gait parameters. ${ }^{9}$ This suggests that higher intensity exercise could have beneficial effects other than improved cognitive function in residents with dementia, for example, a reduced risk of falls. ${ }^{3,9}$ Overall, it is difficult to recommend an exact optimum exercise protocol from the included studies in this review and the current guidelines; however, it appears that a higher intensity, multimodal programme which includes walking 
should be adopted when aiming to maintain or improve cognitive function in nursing home residents with dementia.

Nevertheless, it is unclear whether these cognitive benefits can be maintained long-term, with or without continued exercise. None of the included studies conducted follow-up past the end of the intervention. Additionally, the five studies with the shortest programme durations, ranging from six to fifteen weeks, all maintained or improved cognitive function, ${ }^{9-11,13,14}$ with the fifteen week multimodal programme producing the most significant improvements. ${ }^{9}$ Contrastingly, the longest programme (twenty-four weeks) was the only study to show a decline in MMSE scores, although not significantly. ${ }^{12}$ Since both the latter two studies investigated moderate-to-severe cognitive impairment, it could be suggested that the intervention type and intensity (walking) of the twenty-four week programme was just not effective enough to maintain cognitive levels, as previously discussed. However, perhaps the spread of amyloid plaques and neurofibrillary tangles (primary biological markers of $A D$ ) from the hippocampus to other brain regions, ${ }^{2}$ represent inevitable pathological changes and thus no form of exercise can continue to halt this degenerative condition. To date, the only research which has shown long-term exercise to decrease pathological deposition of these proteins has all been conducted on transgenic mice, ${ }^{20-22}$ making the translation of these findings to humans difficult. ${ }^{23}$ Overall, future studies should investigate whether a multimodal programme is able to maintain the positive effects on cognitive function at twenty-four weeks and beyond, for all stages of dementia.

\section{Social Interaction and Control Groups}

Initially, it could be suggested that incorporating an exercise programme in addition to standard daily activities may provide the most beneficial effects on cognition, since both were continued by the intervention group in the only study to achieve statistically significant improvements. ${ }^{9}$ However, both multimodal programmes were conducted alongside usual activities, ${ }^{9,11}$ so whilst the only difference between the interventions is the dosage of physical activity, this suggests it is the exercise programme which resulted in the better outcome. Similarly, Stevens and Killeen ${ }^{10}$ produced the same results as Thurm et al. ${ }^{11}$ through an exercise programme alone, 
222 implying that standard activities may have had no effect in the latter study. In addition, four

223 studies demonstrated significant cognitive decline in the control groups, suggesting that daily

224 activities alone are unable to maintain cognitive function in residents with dementia. ${ }^{9-12}$ Yet,

225 two studies found no change in cognitive scores in either the intervention or control groups,

226 suggesting equal effect. ${ }^{13,14}$ However such studies failed to provide optimal exercise

227 intervention. Overall, if an optimum exercise programme is used, then this alone may be able to

228 positively affect cognition as well as provide the benefits of standard activities, such as lifting

229 mood, since physical activity is acknowledged as social interaction. ${ }^{10}$ Therefore, this may save

230 nursing homes' time and resources as one exercise programme could provide all potential

231 benefits. Nonetheless, if resources are available, then other daily activities should be included

232 alongside physical activity to provide ongoing entertainment and stimulation.

\section{Limitations}

234 There were a limited number of articles solely targeting nursing home residents, whilst the 235 included studies had relatively small sample sizes. This may reduce the generalisability of the 236 review's findings to the whole population of nursing home residents with dementia. Only 237 English-language studies were included in this review and reference lists of selected studies were not screened for additional references; thus, other relevant articles may have been missed. Moreover, only including nursing home residents also limits the transferability of findings to those with dementia living in the community.

\section{Conclusion}

242 This review has been unable to determine an optimum exercise protocol; however, there is 243 moderate evidence that physical activity can effectively maintain cognitive function in nursing

244 home residents with dementia. Results suggest that aerobic exercise of longer duration may be most effective in maintaining cognitive levels for those with mild-to-moderate cognitive

246 impairment, physical frailties and co-morbidities; whilst multimodal programmes may have the 247 same effect for moderate-to-severe dementia and healthier, less frail residents. One 248 multimodal programme did demonstrate significant improvements in cognitive function. It appears interventions should be of a higher intensity and include walking exercises to achieve 
the greatest benefits. Moreover, combining an exercise programme with standard daily activities appears no more effective than exercise alone. Future research should aim to determine an optimum exercise protocol for this target population and investigate whether the positive effects on cognition can be maintained long-term with continued exercise; thus, trials with extended follow-ups should be conducted.

\section{References}

1. Horr T, Messinger-Rapport B, Pillai JA. Systematic Review of Strengths and Limitations of Randomized Controlled Trials for Non-Pharmacological Interventions in Mild Cognitive Impairment: Focus on Alzheimer's Disease. J Nutr Health Aging. 2015 Feb;19(2):141-153.

2. Phillips C, Baktir MA, Das D, Lin B, Salehi A. The Link Between Physical Activity and Cognitive Dysfunction in Alzheimer Disease. Phys Thera. 2015 Jul;95(7):1046- 1060.

3. Faulk S, Edwards L, Sumrall K, Shelton T, Esalomi T, Payton C, et al. Benefits of Physical Activity on Alzheimer's Disease: A Literature Review. Clinical Kinesiology. 2014;68(3):19-24.

4. Tanigawa T, Takechi $\mathrm{H}$, Arai $\mathrm{H}$, Yamada M, Nishiguchi S, Aoyama T. Effect of physical activity on memory function in older adults with mild Alzheimer's disease and mild cognitive impairment. Geriatr Gerontol Int. 2014 Oct;14(4):758-762.

5. National Institute for Health and Care Excellence. Dementia: supporting people with dementia and their carers in health and social care. London: National Institute for Health and Care Excellence; 2006.

6. Effective Public Health Practice Project. Quality Assessment Tool for Quantitative Studies. Hamilton: Effective Public Health Practice Project; 1998.

7. Armijo-Olivo S, Stiles CR, Hagen NA, Biondo PD, Cummings GG. Assessment of study quality for systematic reviews: a comparison of the Cochrane Collaboration Risk of Bias Tool and the Effective Public Health Practice Project Quality Assessment Tool: methodological research. J Eval Clin Pract. 2012 Feb;18(1):12-18.

8. Evans D. Hierarchy of evidence: a framework for ranking evidence evaluating healthcare interventions. J Clin Nurs. 2003 Jan;12(1):77-84. 
9. Kemoun G, Thibaud M, Roumagne N, Carette P, Albinet C, Toussaint L, et al. Effects of a Physical Training Programme on Cognitive Function and Walking Efficiency in Elderly Persons with Dementia. Dement Geriatr Cogn Disord. 2010 Feb 11;29(2):109-114.

10. Stevens J, Killeen M. A randomised controlled trial testing the impact of exercise on cognitive symptoms and disability of residents with dementia. Contemp Nurse. 2006 FebMar;21(1):32-40.

11. Thurm F, Scharpf A, Liebermann N, Kolassa S, Elbert T, Lüchtenberg D, et al. Improvement of Cognitive Function after Physical Movement Training in Institutionalized Very Frail Older Adults with Dementia. GeroPsych. 2011 Dec;24(4):197-208.

12. Venturelli M, Scarsini R, Schena F. Six-Month Walking Program Changes Cognitive and ADL Performance in Patients With Alzheimer. Am J Alzheimers Dis Other Dement. 2011 Aug;26(5):381-388.

13. Eggermont LHP, Swaab DF, Hol EM, Scherder EJA. Walking the line: a randomised trial on the effects of a short term walking programme on cognition in dementia. J Neurol Neurosurg Psychiatry. 2009 Jul;80(7):802-804.

14. Telenius EW, Engedal K, Bergland A. Effect of a High-Intensity Exercise Program on Physical Function and Mental Health in Nursing Home Residents with Dementia: An Assessor Blinded Randomized Controlled Trial. PLoS One. 2015 May 14;10(5):1-18.

15. van Tulder M, Furlan A, Bombardier C, Bouter L, the Editorial Board of the Cochrane Collaboration Back Review Group. Updated Method Guidelines for Systematic Reviews in the Cochrane Collaboration Back Review Group. Spine. 2003 Jun 15;28(12):1290-1299.

16. Alzheimer's Association. Alzheimer's Association Report: 2015 Alzheimer's disease facts and figures. Alzheimers Dement. 2015 Mar;(11):332-384.

17. World Health Organization. Global Recommendations on Physical Activity for Health. Geneva: World Health Organization; 2010.

18. American College of Sports Medicine. ACSM's Guidelines for Exercise Testing and Prescription. 9th ed. Indianapolis: American College of Sports Medicine; 2013.

19. Department of Health. Start Active, Stay Active: A report on physical activity from the four home countries' Chief Medical Officers. London: Department of Health; 2011. 
307 20. Ke HC, Huang HJ, Liang KC, Hsieh-Li HM. Selective improvement of cognitive function in 308 adult and aged APP/PS1 transgenic mice by continuous non-shock treadmill exercise. Brain $309 \quad$ Res. 2011 Jul 27;14(03):1-11.

310 21. Um HS, Kang EB, Koo JH, Kim HT, Jin L, Kim EJ, et al. Treadmill exercise represses neuronal 311 cell death in an aged transgenic mouse model of Alzheimer's disease. Neurosci Res. 2011 312 Feb;69(2):161-173.

313 22. Kang EB, Kwon IS, Koo JH, Kim EJ, Kim CH, Lee J, et al. Treadmill exercise represses neuronal 314 cell death and inflammation during A beta-induced ER stress by regulating unfolded protein 315 response in aged presenilin 2 mutant mice. Apoptosis. 2013 Nov;18(11):1332-1347.

316 23. Franco R, Cedazo-Minguez A. Successful therapies for Alzheimer's disease: why so many in 317 animal models and none in humans? Front Pharmacol. 2014 Jun 25;5(146):1-13. 
Table 1. Search terms.

\begin{tabular}{ll}
\hline Key concept & Alternative terms \\
\hline Dementia & $\begin{array}{l}\text { Dementia OR Alzheimer* OR "Alzheimer's disease" } \\
\text { "Cognitive function } \\
\text { "Cognitive function" OR "Cognitive decline" OR }\end{array}$ \\
Physical activity & $\begin{array}{l}\text { "Physical activity" OR walk* OR exercise OR inactivity OR } \\
\text { sedentary OR "sedentary lifestyle" } \\
\text { "nursing home" }\end{array}$ \\
\hline
\end{tabular}


Table 2. Methodological quality assessment results.

\begin{tabular}{|c|c|c|c|c|c|c|c|}
\hline \multicolumn{2}{|c|}{ Questions } & \multirow{2}{*}{$\begin{array}{l}\text { Venturelli et al. } 2011 \\
\text { Somewhat likely }\end{array}$} & \multirow{2}{*}{\begin{tabular}{|l|} 
Thurm et al. 2011 \\
Not likely
\end{tabular}} & \multirow{2}{*}{\begin{tabular}{|l|} 
Kemoun et al. 2010 \\
Somewhat likely
\end{tabular}} & \multirow{2}{*}{\begin{tabular}{|l|} 
Telenius et al. 2015 \\
Somewhat likely
\end{tabular}} & \multirow{2}{*}{$\begin{array}{l}\text { Stevens and Killeen } 2006 \\
\text { Somewhat likely }\end{array}$} & \multirow{2}{*}{$\begin{array}{l}\text { Eggermont et al. } 2008 \\
\text { Somewhat likely }\end{array}$} \\
\hline & 1. & & & & & & \\
\hline & 2. & $80-100 \%$ & N/A & $80-100 \%$ & $80-100 \%$ & $80-100 \%$ & $80-100 \%$ \\
\hline & & MODERATE & WEAK & MODERATE & STRONG & MODERATE & MODERATE \\
\hline & 1. & RCT & CCT & RCT & $\mathrm{RCT}$ & RCT & $\mathrm{RCT}$ \\
\hline & 2. & YES & $\mathrm{NO}$ & YES & YES & YES & YES \\
\hline & 3. & YES & N/A & YES & YES & YES & YES \\
\hline \multirow{2}{*}{\multicolumn{2}{|c|}{ B) 4 . }} & YES & N/A & YES & YES & YES & YES \\
\hline & & STRONG & STRONG & STRONG & STRONG & STRONG & STRONG \\
\hline & 1. & NO & $\mathrm{NO}$ & NO & NO & Can't tell & NO \\
\hline \multirow{2}{*}{\multicolumn{2}{|c|}{ C) 2 . }} & N/A & N/A & N/A & N/A & N/A & N/A \\
\hline & & STRONG & STRONG & STRONG & STRONG & WEAK & STRONG \\
\hline D) & 1. & NO & YES & NO & NO & Can't tell & NO \\
\hline \multirow{2}{*}{\multicolumn{2}{|c|}{ D) 2 . }} & Can't tell & YES & Can't tell & Can't tell & Can't tell & Can't tell \\
\hline & & MODERATE & WEAK & MODERATE & MODERATE & MODERATE & MODERATE \\
\hline & 1. & YES & YES & YES & YES & YES & YES \\
\hline \multirow{2}{*}{\multicolumn{2}{|c|}{ E) 2 . }} & YES & YES & YES & YES & YES & YES \\
\hline & & STRONG & STRONG & STRONG & STRONG & STRONG & STRONG \\
\hline & 1. & YES & YES & YES & YES & YES & NO \\
\hline \multirow{2}{*}{\multicolumn{2}{|c|}{ F) 2.}} & $80-100 \%$ & $60-79 \%$ & $80-100 \%$ & $80-100 \%$ & $60-79 \%$ & $80-100 \%$ \\
\hline & & STRONG & MODERATE & STRONG & STRONG & MODERATE & STRONG \\
\hline & 1. & $80-100 \%$ & $80-100 \%$ & $80-100 \%$ & $80-100 \%$ & Can't tell & $80-100 \%$ \\
\hline & 2. & YES & YES & Can't tell & YES & Can't tell & Can't tell \\
\hline & 3. & NO & $\mathrm{NO}$ & YES & NO & NO & NO \\
\hline & 1. & Institution & Institution & Institution & Institution & Institution & Institution \\
\hline & 2. & Institution & Institution & Institution & Institution & Institution & Institution \\
\hline & 3. & YES & YES & YES & YES & YES & YES \\
\hline $\mathrm{H})$ & 4. & Can't tell & NO & Can't tell & YES & NO & YES \\
\hline GL & OBAL RATING & STRONG (1) & WEAK (3) & STRONG (1) & STRONG (1) & MODERATE (2) & STRONG (1) \\
\hline
\end{tabular}


Table 3. Data extraction.

\begin{tabular}{|c|c|c|c|c|c|c|c|c|}
\hline Authors & $\begin{array}{l}\text { Study } \\
\text { Design }\end{array}$ & $\begin{array}{l}\text { Participants and } \\
\text { task }\end{array}$ & Control & Co-morbidities & $\begin{array}{l}\text { Outcome } \\
\text { measures }\end{array}$ & Results & Comments & $\begin{array}{l}\text { Critical } \\
\text { appraisal } \\
\text { score }\end{array}$ \\
\hline $\begin{array}{l}\text { Venturelli et } \\
\text { al. } 2011\end{array}$ & RCT & $\begin{array}{l}5 \text { male and } 30 \\
\text { female } \\
\text { Age: } 84 \pm 5 \\
\text { Moderate-severe } \\
\text { cognitive } \\
\text { impairment } \\
\text { Duration of } \\
\text { residence (months): } \\
21.5 \pm 3.7 \text { (IG) and } \\
20.7 \pm 5.4 \text { (CG) } \\
24 \text {-week walking } \\
\text { programme (30 } \\
\text { minutes, } 4 \text { x week) }\end{array}$ & $\begin{array}{l}\text { Routine care } \\
\text { incorporating } \\
\text { daily } \\
\text { organized } \\
\text { activities, e.g. } \\
\text { bingo, sewing } \\
\text { and music } \\
\text { therapy }\end{array}$ & $\begin{array}{l}\text { Included: } \\
\text { constant } \mathrm{SpO}_{2}>85 \% \\
\text { during walking, } \\
\text { osteoporosis, } \\
\text { hypertension, } \\
\text { depression } \\
\text { Excluded: } \\
\text { severe heart disease, } \\
\text { low haemoglobin } \\
\text { saturation } \\
\text { Mobility: } \\
\text { Absence of mobility } \\
\text { limitations }\end{array}$ & MMSE & $\begin{array}{l}\text { IG had a slower decline } \\
\text { in MMSE scores (- } \\
13 \%) \text { demonstrating no } \\
\text { significant change, } \\
\text { therefore maintained } \\
\text { cognitive levels. CG } \\
\text { showed a statistically } \\
\text { significant decrease in } \\
\text { MMSE scores } \\
(-47 \%)\end{array}$ & $\begin{array}{l}\text { Maintained } \\
\text { constant but fastest } \\
\text { walking speed } \\
\text { possible (no } \\
\text { accelerating or } \\
\text { stopping); } \\
\text { Average baseline } \\
\text { MMSE score stated } \\
\text { for IG differed } \\
\text { between results } \\
\text { table and } \\
\text { description of } \\
\text { results }\end{array}$ & Strong $=1$ \\
\hline $\begin{array}{l}\text { Thurm et al. } \\
2011\end{array}$ & CCT & $\begin{array}{l}4 \text { male and } 11 \\
\text { female } \\
\text { Age: } 74-92 \\
\text { Mild-severe } \\
\text { cognitive } \\
\text { impairment } \\
\text { 10-week } \\
\text { multimodal, chair- } \\
\text { based training } \\
\text { including } \\
\text { Strengthening, } \\
\text { coordination, } \\
\text { balance, flexibility } \\
\text { and stamina (45 } \\
\text { minutes, } 2 \times \text { week) } \\
\text { whilst continuing } \\
\text { standard daily } \\
\text { activities }\end{array}$ & $\begin{array}{l}\text { Standard daily } \\
\text { activities, e.g. } \\
\text { handicrafts, } \\
\text { singing, } \\
\text { cooking and } \\
\text { movies } \\
\text { afternoons }\end{array}$ & $\begin{array}{l}\text { Included: } \\
\text { Hypertension, } \\
\text { depression } \\
\text { Excluded: } \\
\text { sensory impairment } \\
\text { (hemiplegia, } \\
\text { paraplegia) } \\
\text { Mobility: } \\
\text { Very frail, relied } \\
\text { partly or constantly } \\
\text { on walking aids }\end{array}$ & ADAS-Cog & $\begin{array}{l}\text { CG showed statistically } \\
\text { significant } \\
\text { deterioration in total } \\
\text { ADAS-cog score } \\
\text { (average } 3.9 \text { error } \\
\text { points) whereas IG had } \\
\text { statistically } \\
\text { insignificant } \\
\text { improvement (average } \\
\text {-3.7 error points). IG } \\
\text { showed statistically } \\
\text { significant } \\
\text { improvement in the } \\
\text { ADAS-Cog } \\
\text { orientation/praxis } \\
\text { subscore (average - } 2.7 \\
\text { error points) whereas } \\
\text { CG showed no change }\end{array}$ & $\begin{array}{l}\text { ADAS-cog scores } \\
\text { represent difference } \\
\text { scores (post minus } \\
\text { pre scores). } \\
\text { Negative scores } \\
\text { indicate } \\
\text { improvement; } \\
\text { positive scores } \\
\text { indicate } \\
\text { deterioration in } \\
\text { cognitive function }\end{array}$ & Weak = 3 \\
\hline
\end{tabular}




\begin{tabular}{|c|c|c|c|c|c|c|c|c|}
\hline $\begin{array}{l}\text { Kemoun et al. } \\
2010\end{array}$ & $\mathrm{RCT}$ & $\begin{array}{l}8 \text { male and } 23 \\
\text { female } \\
\text { Age: } 81.8 \pm 5.3 \\
\text { Moderate-severe } \\
\text { cognitive } \\
\text { impairment } \\
\text { 15-week physical } \\
\text { activity programme } \\
\text { combining walking, } \\
\text { equilibrium and } \\
\text { stamina exercises (1 } \\
\text { hour, } 3 \text { x week) } \\
\text { whilst continuing } \\
\text { standard daily } \\
\text { activities }\end{array}$ & $\begin{array}{l}\text { No physical } \\
\text { activities; } \\
\text { Standard daily } \\
\text { activities, e.g. } \\
\text { pottery, } \\
\text { painting, soft } \\
\text { gymnastics } \\
\text { and outings }\end{array}$ & $\begin{array}{l}\text { Unknown co- } \\
\text { morbidities } \\
\text { Mobility: } \\
\text { ability to walk } 10 \\
\text { meters without } \\
\text { technical assistance }\end{array}$ & French ERFC & $\begin{array}{l}\text { IG showed a } \\
\text { statistically significant } \\
\text { increase in ERFC score } \\
\text { (from } 26.81 \pm 6.42 \text { to } \\
30.38 \pm 7.66 \text { ) } \\
\text { compared to the CG for } \\
\text { whom scores } \\
\text { deteriorated (from } \\
28.33 \pm 7.11 \text { to } 23.23 \pm \\
8.37 \text { ). A significant } \\
\text { correlation between } \\
\text { improved ERFC score, } \\
\text { walking speed and } \\
\text { stride length was also } \\
\text { observed. }\end{array}$ & $\begin{array}{l}\text { Soft gymnastics } \\
\text { included within } \\
\text { standard daily } \\
\text { activities may } \\
\text { constitute as } \\
\text { physical activity }\end{array}$ & Strong $=1$ \\
\hline $\begin{array}{l}\text { Telenius et al. } \\
2015\end{array}$ & $\mathrm{RCT}$ & $\begin{array}{l}43 \text { males and } 120 \\
\text { females } \\
\text { Age: } 86.7 \pm 7.4 \\
\text { Moderate cognitive } \\
\text { impairment } \\
\text { Duration of } \\
\text { residence (months): } \\
26 \pm 24.8 \text { Included } \\
\text { co-morbidities: } \\
\text { 12-week high- } \\
\text { intensity } \\
\text { strengthening and } \\
\text { balance exercise } \\
\text { programme (50-60 } \\
\text { minutes, } 2 \times \text { week) }\end{array}$ & $\begin{array}{l}\text { Leisure } \\
\text { activities } \\
\text { including light } \\
\text { physical } \\
\text { activity, } \\
\text { reading, } \\
\text { playing } \\
\text { games, } \\
\text { listening to } \\
\text { music and } \\
\text { conversations } \\
\text { (50-60 } \\
\text { minutes, } 2 \mathrm{x} \\
\text { week) }\end{array}$ & $\begin{array}{l}\text { Included: } \\
\text { previous stroke, PD, } \\
\text { depression } \\
\text { Excluded: } \\
\text { medically unstable, } \\
\text { psychotic } \\
\text { Mobility: } \\
\text { able to walk six } \\
\text { meters with or } \\
\text { without walking aid } \\
\text { ( } 1 / 3 \text { able to walk } \\
\text { independently) }\end{array}$ & MMSE & $\begin{array}{l}\text { No significant changes } \\
\text { were observed in } \\
\text { MMSE scores for IG or } \\
\text { CG, therefore cognitive } \\
\text { function was } \\
\text { maintained }\end{array}$ & $\begin{array}{l}\text { MMSE was not a } \\
\text { primary outcome } \\
\text { measure }\end{array}$ & Strong $=1$ \\
\hline $\begin{array}{l}\text { Stevens and } \\
\text { Killeen } 2006\end{array}$ & $\mathrm{RCT}$ & $\begin{array}{l}19 \text { male and } 56 \\
\text { female } \\
\text { Age: } 80.5 \\
\text { Mild-moderate } \\
\text { cognitive } \\
\text { impairment }\end{array}$ & $\begin{array}{l}\text { CG } 1=\text { no } \\
\text { intervention } \\
\text { CG } 2=\text { social } \\
\text { visit from the } \\
\text { researcher } \\
\text { discussing }\end{array}$ & $\begin{array}{l}\text { Included: vascular } \\
\text { and degenerative } \\
\text { diseases, e.g. arthritis, } \\
\text { PD } \\
\text { Mobility: }\end{array}$ & $\begin{array}{l}\text { The Clock- } \\
\text { Drawing Test }\end{array}$ & $\begin{array}{l}\text { Both CGs increased in } \\
\text { their post-test scores } \\
\text { and this score } \\
\text { difference was } \\
\text { statistically significant } \\
\text { for CG } 2(\mathrm{p}<.000)\end{array}$ & $\begin{array}{l}\text { Mean post-test } \\
\text { scores were } \\
\text { subtracted from } \\
\text { mean pre-test } \\
\text { scores. }\end{array}$ & $\begin{array}{l}\text { Moderate = } \\
2\end{array}$ \\
\hline
\end{tabular}




$\begin{array}{lll}\text { 12-week aerobic } & \text { health-related } & \text { physically capable of } \\ \text { exercise programme } & \text { issues (30 } & \text { undertaking gentle } \\ \text { with music (30 } & \text { minutes, 3x } & \text { exercise (included } \\ \text { minutes, 3 x week) } & \text { week) } & \text { frail, and wheelchairs } \\ & & \text { users) }\end{array}$

$\begin{array}{lll}\begin{array}{l}\text { Eggermont et } \\ \text { al. } 2008\end{array} & \text { RCT } & \text { 18 male and } 79 \\ & & \text { female } \\ & \text { Age: } 85.4 \\ & \text { Mild-moderate } \\ & \text { cognitive } \\ & \text { impairment } \\ & \text { 6-week walking } \\ & \text { programme (30 } \\ & \text { minutes, } 5 \times \text { week })\end{array}$

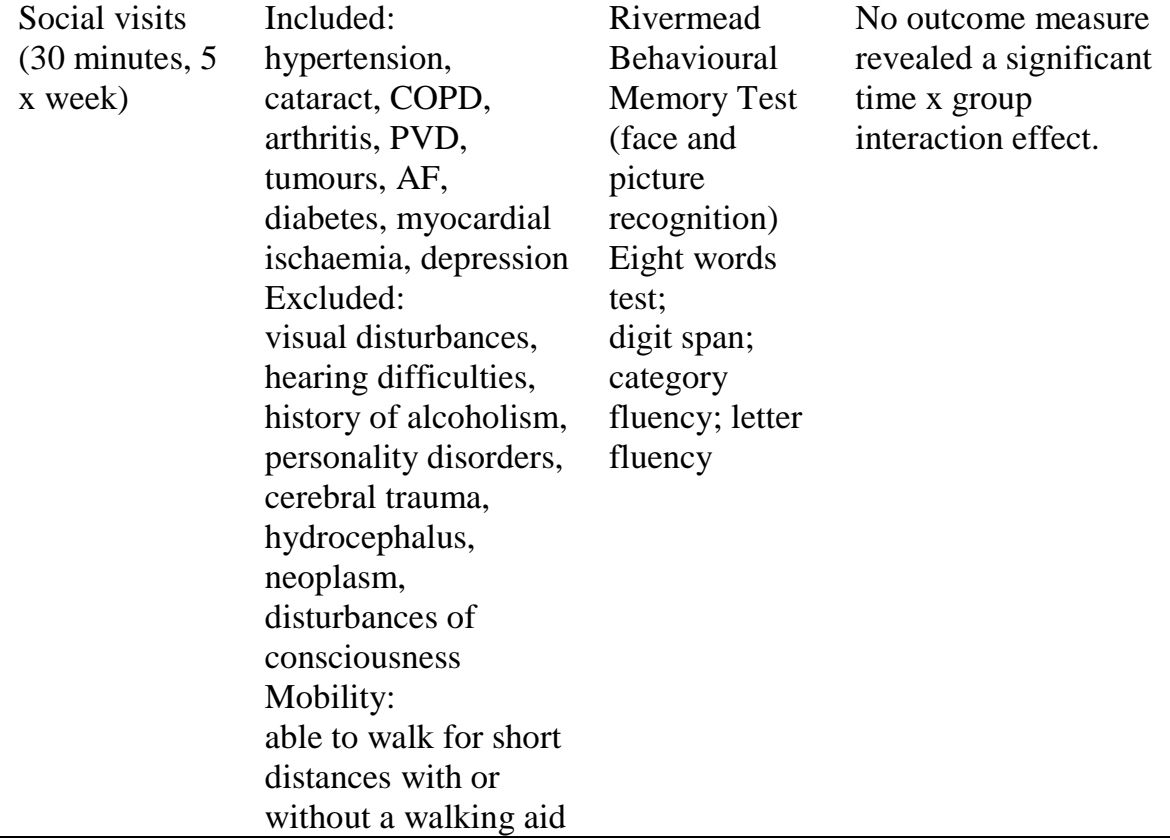
time $\mathrm{x}$ group

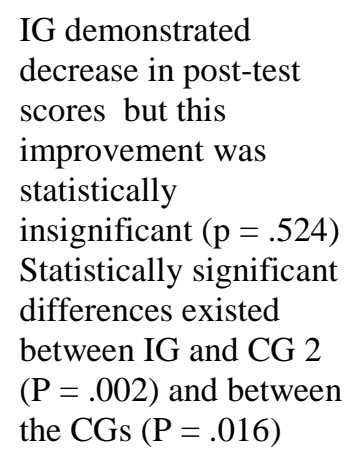

Walked at selfselected speed with short rests included. It was concluded that the intervention lacked beneficial effects on cognition as improvements were not made; however, cognitive function was maintained. cognitive decline. scores suggest

improved cognitive function
Strong $=1$

\section{n}

on 

Figure 1. PRISMA flow-diagram of search.

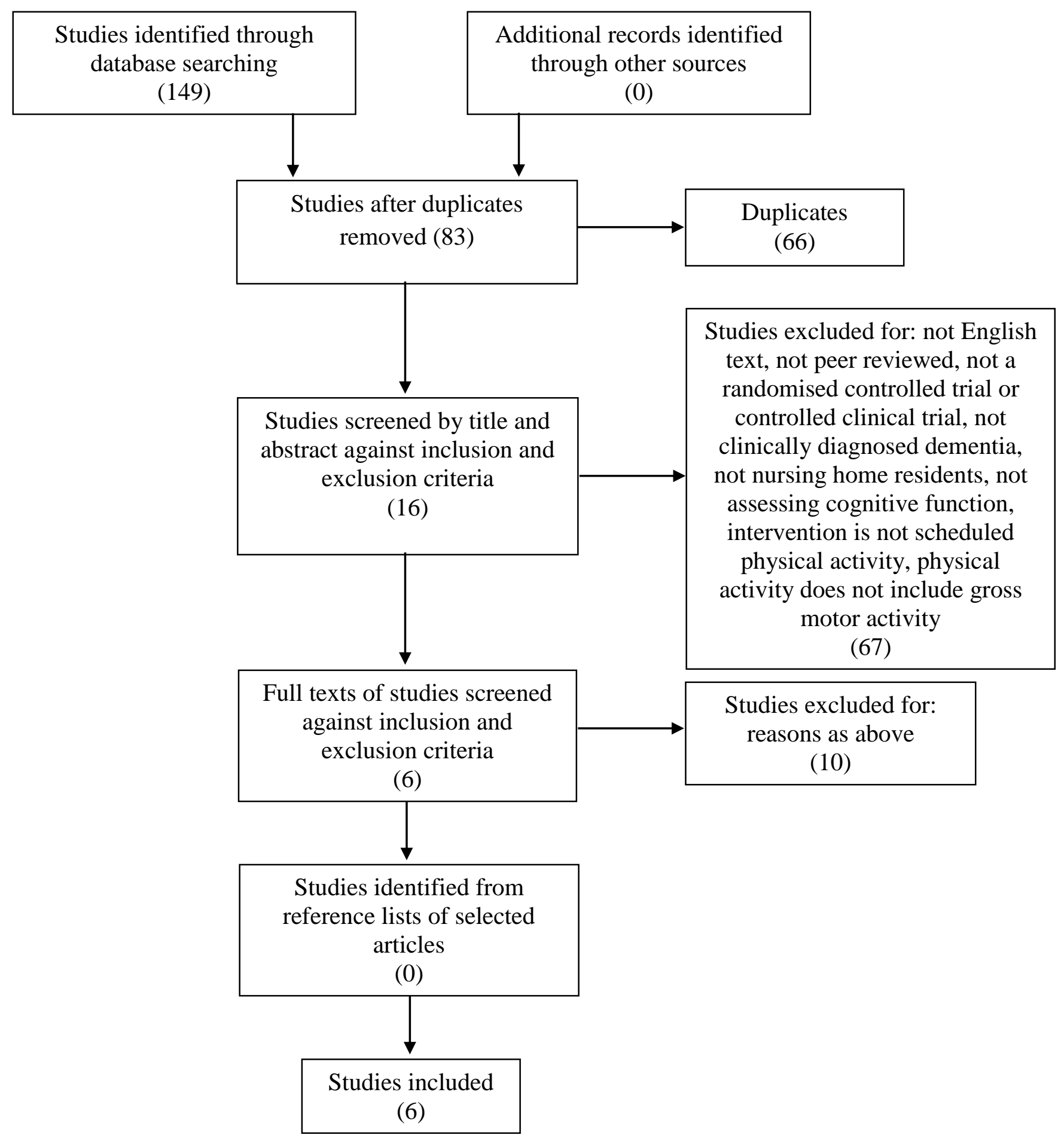

